\title{
MENTALIZÁCIÓRA IRÁNYULÓ IGÉNY ÉS EGYÜTTMÜKÖDÉS INTEGRATÍV ALKUTÁRGYALÁSBAN*
}

\author{
BERNÁTH ÁGNES - KOVÁCS JUDIT
}

DE BTK Pszichológiai Intézet,

Szociál- és Munkapszichológiai Tanszék

E-mail: bernath.agnes@arts.unideb.hu; kovacs.judit@arts.unideb.hu

Beérkezett: 2014. október 10. - Elfogadva: 2014. december 20.

\begin{abstract}
A mentalizációra irányuló igény társas helyzetben a partner mentális állapotának (hiedelmeinek, érzéseinek, motívumainak) a megismerésére irányuló beszámolt törekvés. A mentalizációs jelenségkör vonatkozásában az eddigi kutatások a mentalizációs teljesítmény társas viselkedésben betöltött szerepére irányultak, jellemzöen a proszociális viselkedésre.

A kutatás a mentalizációra irányuló igény szerepét vizsgálja több szempontos tárgyalások során. Elvárásaink szerint a mentalizációra irányuló erős igény segíti a személyeket abban, hogy feltérképezzék alkupartnerük övékétól eltérö prioritásait és az alkuhelyzet integratíu potenciálját jól kihasználó egyezségeket kössenek.

A 75 tárgyalásból $(N=150)$ származó tapasztalataink szerint azok a párok, amelyekben a személyeknek átlagosan magas a mentalizációs igénye, valóban jobban kihasználják az integratív alkuteret, de nem a feladat szerkezetének jobb megragadása, hanem a partnerhez való erősebb alkalmazkodás miatt. A magasabb mentalizációs igény egyúttal az integratív alku viselkedéses stílusjegyeivel is együtt járt.
\end{abstract}

Kulcsszavak: mentalizáció, mentalizációra irányuló igény, több szempontos integratív alkutárgyalás

* A publikáció elkészítését a TÁMOP-4.2.2/B-10/1-2010-0024 számú projekt támogatta. A projekt az Európai Unió támogatásával, az Európai Szociális Alap társfinanszírozásával valósult meg. 


\section{BEVEZETŐ}

Ki ne szeretne a mindennapi élet alkuhelyzeteiben jobb üzleteket kötni? Sokszor persze a jóérzés visszatart bennünket attól, hogy túl nagy követelésekkel álljunk elő, de vannak olyan alkuhelyzetek is, melyekben mindkét fél jól járhat, feltéve, hogy mögé néznek a problémának, alaposan megismerik egymás szempontjait, és azonosítják azokat a pontokat, ahol prioritás-különbözőségeik vannak, hogy egymás javára kölcsönös engedményeket tehessenek.

Ez a tanulmány azt mutatja meg, hogy ezt a folyamatot jó irányba befolyásolja, ha a személyek a másik nézőpontját megismerni akaró hozzáállással közelítenek a tárgyaláshoz, bár ez a hozzáállás nem feltétlenül a jobb megismerést segíti, sokkal inkább az alkalmazkodást.

\section{Mentalizációs képesség, mentalizációs igény és szerepük a társas viselkedésben}

A mentalizálás arra a folyamatra utal, amikor megpróbáljuk megérteni a másik személy mentális állapotait, mint például gondolatait, szándékait, hangulatát, motívumait (Kinderman, Dunbar és Bentall, 1998; Slaughter és REPACHOLI, 2003). A mentalizálás kielégítő működésének az eredményeképpen az emberek mások viselkedésének megindítóiról alkotnak képet. Az intencionális emberi cselekedet (TOMASELlO, 2002) indítéka és szándéka tehát a viselkedés hátterében álló tudattartalmak feltérképezése által ismerhető meg. A mentalizáció így segíti a társas szituációkban való gördülékeny interakciók lefolytatását és fenntartását.

A mentalizálás a mentalizációs képesség (elmeteória) segítségével valósul meg. Ez a képesség többféle részképességet ölel fel (érzelmek, hangulatok, szándékok, hiedelmek, kogníciók felismerése, szándékolatlan sértés felismerése). E különböző részképességek a mentalizációs képességet mérő tesztek diverzitásában is manifesztálódnak.

A mentalizációs képesség fejlődését és működését ez idáig többnyire a fejlődésés klinikai lélektani kutatások állították az érdeklődés fókuszába, noha mára egyre növekvő számban lehetünk tanúi a mentalizációs képesség egészséges felnőtt személyek társas interakcióiban betöltött szerepét bemutató vizsgálatoknak.

Az elmeteória mértékének az együttmüködési hajlammal pozitív kapcsolata van (PAAL és BERECZKEI, 2007). A mentalizációs képesség proszociális orientációval való feltételezett szoros kapcsolatát tovább támogatja az empátiával (WAKABAYASHI és KATSUMATA, 2011) és érzelmi intelligenciával való pozitív korrelációja (FERGUSON és AUSTIN, 2010), valamint a mentalizációs képesség megbocsátásban betöltött jótékony szerepe (ExLINE, BAUMEISTER, ZELL, KRAFT és Witwliet, 2008; Kovács, PÁntya, Bernáth, Máth és Hidegkuti, 2012; MCCullough, Worthington és RACHAL, 1997). Ugyancsak illeszkedik a felvázolt irányvonalba a mentalizációs képesség negatív kapcsolata a manipulációra való hajlammal és a machiavellizmussal (Ali és CHAMORro-Premuzic, 2010; Lyons, CALDWELl és SHULTZ, 2010). 
A mentalizációra irányuló igény az interakciós partner mentális állapotainak a feltérképezésére irányuló beszámolt törekvés. Nem képességet vagy teljesítményt jelöl tehát, hanem azt fejezi ki, hogy mekkora mértékű motivációt mutat arra az egyén, hogy megismerje a mentális állapotokat. A mentalizáció motivációs megközelítése mondhatni egészen új keletủ a pszichológiában. A mentalizáció képességtől eltérő megközelítése elsőként ESPERGER Zsófia és BERECZKEI Tamás munkájában bukkant fel (2011), akik a spontán mentalizációt vezették be és mérték. A spontán mentalizáció esetükben a társas helyzetek mentális állapotokra utaló terminusokkal való leírására vonatkozott. Mindemellett a képesség a motivációtól való megkülönböztetése erős hagyományokkal rendelkezik a megismerés szociálpszichológiájában (lásd például MAIO és EsSES, 2001). A mentalizációra irányuló igény mérésére szolgáló skála segítségével a mentális állapotok megismerésére és a zökkenőmentes interakciókra való igényt, valamint a mentalizációval mint tevékenységgel kapcsolatos attitűdöt mérhețük (BERNÁTH és KoVÁCS, 2013).

A mentalizációs igény társas viselkedésben betöltött szerepét vizsgáló eddigi kutatásaink szerint ez az igény egyrészt nincs erős kapcsolatban a mentalizációs képességgel (BERNÁTH, 2014), másrészt a proszociális viselkedést a mentalizációs képesség befolyásához mérve hasonló irányban alakítja. Például segíti a megbocsátást (PAPP, BERNÁTH és TóTH, 2014).

A beszámolt kutatásban azt vizsgáljuk, hogy az erős mentalizációs igény vajon hozzájárul-e ahhoz, hogy több szempontos integratív tárgyalásokban az integratív potenciált jobban kihasználó alkuk szülessenek. A proszocialitás az integratív tárgyalásokban az együttes profit szolgálatában jelenik meg. Mivel a tárgyalások információhiányos helyzetek, különösképpen alkalmasak arra, hogy megvizsgáljuk, vajon a nagyobb mentalizációs igény hozzájárul-e a feladatszerkezet jobb megismeréséhez a partner prioritásainak feltérképezése által (a prioritás is egy mentális állapot, abban az értelemben, hogy azt jelzi, valakinek egy bizonyos dolog fontosabb, többre értékelt, mint a másik).

\section{Integratív tárgyalások}

A tárgyalási helyzetek a mindennapi élet velejárói, mivel számos olyan szituáció adódik az életben, ahol megegyezést kell kötni más emberekkel. Az alkutárgyalási helyzetek a tárgyalási helyzetek egy speciális osztályát képviselik. Olyan kétszemélyes helyzetek, melyekben a felek észlelik, hogy lehetőség van elérni jobb kimenetelt az alku megkötésével (DEUTSCH és KRAUSS, 1981), mintha nem egyeznének meg. Az alku az interperszonális konfliktus megoldása, amely attól függően, hogy a felek érdekeit mennyire szolgálja, többféle lehet. Az alkukonfliktusok integratív megoldása által mindkét fél érdeke kielégül. (Ez persze nem lehetséges minden alkuhelyzetben, csak az ún. „integratív potenciállal” jellemezhető alkuhelyzetekben, lásd később). Az integrációra lehetőséget adó helyzetekben az integráció csak akkor jöhet létre, ha az emberek nemcsak a saját érdekükkel törődnek, hanem a partnerük érdeke is foglalkoztatja őket valamilyen mértékben (DE DREU, Beersma, Steinel és van Kleef, 2007; De Dreu, Weingart és Kwon, 2000). Az 
együttműködő motívum segít maximalizálni mindkét fél nyereségét (PRUITT és Rubin, 1986 idézi: VAN LANGE és DE Dreu, 2007). Azt, hogy a konfliktusban álló tárgyalófelek törődnek-e a másik érdekével, számos tényező befolyásolja. Az alapvetően együttműködő személyes orientáción túl számos más tényező is. Például jobban törődnek másokkal az emberek, ha a hangsúly a veszteségek elkerülésére esik (De Dreu, Beersma, Stroebe és Euwema, 2006). Kutatásunkban a mentalizációs igény hatására irányítjuk a figyelmet.

A több szempontos integratív tárgyalási alkuhelyzetek a tárgyalási helyzeteknek integratív potenciállal bíró, sajátos osztályát képviselik. Két vagy több szempontra kiterjedően kell bennük a feleknek egyezséget kötni az egyéni prioritások kölcsönös figyelembevételét megengedő feltételek mellett. A kölcsönös engedménytételekkel a felek lemondhatnak követeléseikről egy számukra kevésbé fontos szempont mentén, hogy cserébe engedményeket kapjanak a tárgyaló partnerüktől számukra fontosabb szempont(ok) mentén (PRUITT, 2012).

A prioritás ezekben az alkuhelyzetekben tehát bizonyos szempontok elsődlegességét jelenti az egyes szempontok egyes megegyezési opcióinak hasznosságát illetően. Az integratív helyzetekben a prioritások mentén elindulhat egy kölcsönösen jó egyezség kidolgozása. A kölcsönös engedménytételt (logrolling) segíti, ha a prioritások tökéletes komplementaritást mutatnak. A logrolling által mindkét fél sokkal jobb eredményre juthat, mint tenné, ha szempontonként haladva egyszerű kompromisszumot kötnének, amelyben minden szempont szerint egy középső, se nem túl veszteséges, se nem igazán nyereséges megoldásban egyeznének meg. Az efféle megoldást a tárgyalás disztributív megoldásának tekintjük, amihez képest a logrollinggal elérhető többlet adja az alku integratív potenciáliát.

A logrollingot alkalmazó integratív tárgyalás nemcsak eredményében, de stílusában is különbözik a disztributív tárgyalási stílustól. A disztributív tárgyalókra az egy szempontos ajánlatok, a saját nézőpontjuk érvekkel való bőséges alátámasztása és a negatív megiegyzések a jellemzők, az integratív tárgyalókra pedig a másik nézőpontja iránti érdeklődés, a több szempontos ajánlatok és a pozitív érzelmi megjegyzések (lásd például Pruitt, 1981; Schei, Rognes és Shapiro, 2011; WEINGART, BRETT, OLEKALNS és SMITH, 2007; WeINGART, THOMPSON, BAZERMAN és CARROLL, 1990).

Ahogyan említettük, az integrációt számos tényező befolyásolja. Például javítja, ha nincs túl nagy időnyomás alatt a tárgyalás, ha a tárgyalók tudják, hogy vannak összességében vett jobb megoldások, illetve ha együttműködésre kész, nyitott, konstruktív hozzáállással ülnek le tárgyalni (BAZERMAN, CurHan, MOORE és VALLEY, 2000). A mentalizációs igényt a nyitott, konstruktív hozzáállás részének tekințük, s azt vizsgáljuk, hogy valóban segíti-e az integratív potenciál kiaknázását, és vajon azt a feladathelyzet jobb megismerése által teszi-e. 


\section{VIZSGÁLAT}

Kutatásunkban arra voltunk kíváncsiak tehát, hogy gyakorol-e hatást a személyek mentalizációra irányuló igényének a mértéke az alku kimenetelére több szempontos interperszonális alkuhelyzetben, és ha igen, hogyan. Az alkuk integratív potenciáljának a jobb kihasználását az alkuviselkedés együttműködő, proszociális mozzanataként konceptualizáltuk. Segíti-e a mentalizációra irányuló igény a különböző prioritások megismerését? Segíti-e az integratív alkutér kihasználását? Milyen kommunikációs stíluselemekkel áll kapcsolatban?

A mentalizációs igénynek az integratív potenciál eredményesebb kihasználására gyakorolt pozitív hatását a mentalizációs képességnek a proszociális viselkedéssel való kapcsolata alapján tételeztük fel (lásd például EXLINE és mtsai, 2008; KovÁCs és mtsai, 2012; PAAL és BereczkeI, 2007; WaKabayashi és Katsumata, 2011). Mivel azonban a mentalizációra irányuló igény nem mutat szoros kapcsolatot a mentalizáció képességével (BERNÁTH és KOVÁCS, 2014; BERNÁTH, 2014), a kérdésekre adandó válasz nem triviális.

\section{Hipotézisek}

H1: Feltételezzük, hogy a magasabb mentalizációs igénnyel rendelkező személyek által kötött alkuk jobban integráltak, mint az alacsonyabb mentalizációs igénnyel rendelkező személyek által kötöttek.

H2: Feltételezzük, hogy a magas mentalizációra irányuló igény az integratív tárgyalási stílus kommunikációs stílusjegyeivel jár együtt (prioritások feltérképezése, a több pozitív, kevesebb negatív megnyilvánulás, kevesebb manipuláció és hazugság).

H3: Feltételezzük, hogy a magasabb mentalizációs igénnyel jellemezhető személyek az alkufeladat szerkezetét a komplementer prioritásokkal jobban feltérképezik és megismerik.

\section{Vizsgálati személyek és eljárás}

A vizsgálatban 150 fő vett részt, 101 nő és 49 férfi, akik átlagéletkora 21,73 év volt (szórás: 2,16 év). A vizsgálati személyeket egy debreceni iskolaszövetkezet segítségével toboroztuk. A laboratóriumba érkezésük után a személyek a Mentalizációra irányuló igény skálát töltötték ki (BERNÁTH és KovÁcs, 2013), majd párokban tárgyaltak. Egy vizsgálati ülés maximum 14 fó fogadására teremtett lehetőséget, így több ülésben történt az adatok felvétele. Az alkutárgyalásokat a maximum 7 pár külön termekben, párhuzamosan folytatta, vizsgálatvezetők jelenlétében. Az alkut hangfelvétellel rögzítettük, hogy a tárgyalások szövegkorpuszait, így második hipotézisünket elemezni tudjuk. Az alkutárgyalásra maximum 20 perc állt a vizsgálati személyek rendelkezésére, előtte pedig maximum 10 perc felkészülési idejük volt. A tárgyalás befejeztével egy utókérdőívet töltöttek ki a tárgyalók. A vizsgálatban való részvétel hozzávetőleg 1 órát vett igénybe. 
Az alkutárgyalásban megszerzett kísérleti tallérok számát a tárgyalások végeztével forintra konvertáltuk, és a diákszövetkezet közvetítésével a keresetet a résztvevők bankszámlájára utaltuk.

\section{Módszer}

\section{A mentalizációra irányuló igény mérése}

A személyek mentalizációra irányuló igényét a mentalizációs igény kérdőívvel mértük (BERNÁTH és KOVÁCS, 2013). A skála három faktort tartalmaz: a másik mentális állapotainak megismerésére irányuló igényt; a zavartalan interakciók iránti igényt; valamint a mentalizációs tevékenységre irányuló attitűdöt. A hipotézisek teszteléséhez valamennyi faktort figyelembe vettük, a faktorokhoz tartozó állítások átlagértékeit alapul véve. Az első faktorba olyan állítások estek, amelyek $a$ másik személy mentális állapotainak megismerésére való igényt fejezik ki (például „Ha beszélek egy emberrel, mindig igyekszem az ő nézőpontjából is átgondolni a dolgokat.”). A második faktor a gördülékeny, zavartalan interakciók iránti igényt fejezi ki (például „Kényelmetlenül érzem magam, ha nem értem, hogy amit mondok, vagy teszek, mit jelenthet a másiknak.”). A harmadik faktor állításai jelentésük szerint $a$ mentalizáció müvelete iránti attitüdöt fejezik ki (például „Szeretem elemezni, hogy milyen a másik szándéka felém.”). Az alskálák valamennyi esetben megbízhatónak mondhatók (Cronbach-alpha >0,6).

\section{Az integratív tárgyalási alkufeladat}

A tárgyalási feladatot SCHEI, Rognes és SHAPIRO (2011) alkutárgyalási feladata mintájára készítettük, ami a klasszikus eladó-vevő integratív alkutárgyalási feladatokon alapul (PruiTT és LEWIS, 1975). A feladat lényege, hogy két személynek, esetünkben egy állatfarm-igazgatónak és egy hentesbolt tulajdonosának, meg kellett egyezniük három dologban. Abban, hogy hányféle húst szállítson az állatfarm tulajdonosa a hentesboltba, hogy azt milyen fizetési határidő mellett és milyen kiszállítási idővel tegye. Mindkét személy kapott egy táblázatot, amelyben láthatta a saját hasznát az egyes megegyezési opciókhoz tartozóan, viszont azt hangosan nem mondhatták ki a tárgyalás alatt. (A feladathoz tartozó instrukciókat lásd az 1. mellékletben.) Minden szempontban (húsféleségek [állatfajták] száma, kiszállítási idő, fizetési határidő) kilenc opció közül volt lehetőségük egyben megegyezni. A feladatot úgy konstruáltuk meg, hogy a kiszállítási idő a hentesbolt tulajdonosának volt a legfontosabb szempont, hiszen ebben kereshetett a legtöbbet, a fizetési határidő pedig az állatfarm tulajdonosának. Amennyit a boltos a kiszállítási időben maximálisan kereshetett, ha a számára legnyereségesebb opcióban egyeztek meg, a legiobb esetben pontosan ugyanannyit kereshetett az állatfarm-igazgató is a fizetési határidő vonatkozásában. A húsféleségek száma egyformán volt fontos mindkét félnek, minél több húsféleségben tudtak megegyezni, annál több nyereséget jelentett a boltosnak, az állatfarm-igazgatónak pedig pon- 
tosan ugyanannyival kevesebb nyereséget. A nyereségtáblázatokat lásd a 2. mellékletben. A feladatban a szerepek ily módon ekvivalensek voltak, amelyre a szerepek elnevezésében is utaltunk (hentesbolt-tulajdonos, állatfarm-igazgató), azok között semmilyen alá-fölé rendeltségi viszonyt nem implikált az elnevezés.

\section{Vizsgálati utókérdőív}

A tárgyalás befejeztével egy utókérdőívet töltöttek ki a tárgyalók, melyben a partnerükkel kapcsolatos észrevételekre, valamint a feladat struktúrájának interpretációjára kérdeztünk rá. E kérdőívből tanulmányunk szempontjából a prioritások tudatosulását fölmérő kérdéseknek van jelentősége. Ezek a kérdések: „A kiszállítási idő volt a másik számára a legfontosabb”; „A tenyésztett állatfajták száma volt a másik számára a legfontosabb”; „A fizetési határidő volt a másik számára a legfontosabb”. A feladatot jól reprezentáló eladó (állatfarm-igazgató) érti, hogy a másiknak a kiszállítási idő a legfontosabb, a fizetési határidő pedig a legkevésbé fontos, s a feladatot jól értő vevő (hentesbolt-tulajdonos) érti, hogy a másiknak a fizetés a legfontosabb, a kiszállítás a legkevésbé.

\section{Eredmények}

Az első hipotézisünk a mentalizációra irányuló igény és az alku integratív potenciálja kihasználásának az összefüggésére vonatkozott. Az integratív potenciál kihasználását a pár össznyereségében mérhetjük. A hipotézis tesztelését korrelációszámítással végeztük. Szignifikáns kapcsolatot mutat a pár össznyeresége és a mentalizációs igény első faktora (a tulajdonképpeni mentalizációs igény) ( $r=$ $0,17 ; p<0,05)$ (1. táblázat). Mivel az alkufolyamat párban történik, s számíthat, hogy egy erős mentalizációs igényű személy egy másik ugyanilyen erős igényü személlyel tárgyal vagy esetleg egy olyannal, akinek ez az igénye csekély, érdemes ezt az összefüggést a pár szintjén is megvizsgálni. A mentalizációs igény és az össznyereség közötti összefüggés erősebbé válik, ha a párt alkotó személyek összesített mentalizációs igényét (értve ezen a skála első faktorába eső itemek átlagainak a párt jellemző összegét) vetjük össze az összesített nyereséggel $(r=0,24 ; p<0,05)$.

1. táblázat. A mentalizációs igény egyéni és össznyereséggel való korrelációs összefüggései (Pearson-féle korreláció) és leíró statisztikái

\begin{tabular}{|l|c|c|c|c|c|}
\hline & Átlag & Szórás & 1. & 2. & 3. \\
\hline 1. Mentalizációs igény & 5,51 & 0,82 & 1 & \multicolumn{2}{|c|}{} \\
\hline 2. Egyéni nyereség & 68917 & 18295 & 0,10 & 1 & \\
\hline 3. Össznyereség & 138008 & 12800 & $\mathbf{0 , 1 7 ^ { * }}$ & $0,34^{* *}$ & 1 \\
\hline
\end{tabular}

** A korreláció 0,01-es szinten szignifikáns.

* A korreláció 0,05-ös szinten szignifikáns. 
Az eredmények gyenge, de szignifikáns összefüggést mutatnak tehát a mentalizációs igény és az integratív potenciál kihasználása között (lásd 1. ábra). A mentalizációra irányuló igény másik két faktora nem mutatott szignifikáns korrelációt az alkuban megszerzett nyereséggel, így arról nem számolunk be.

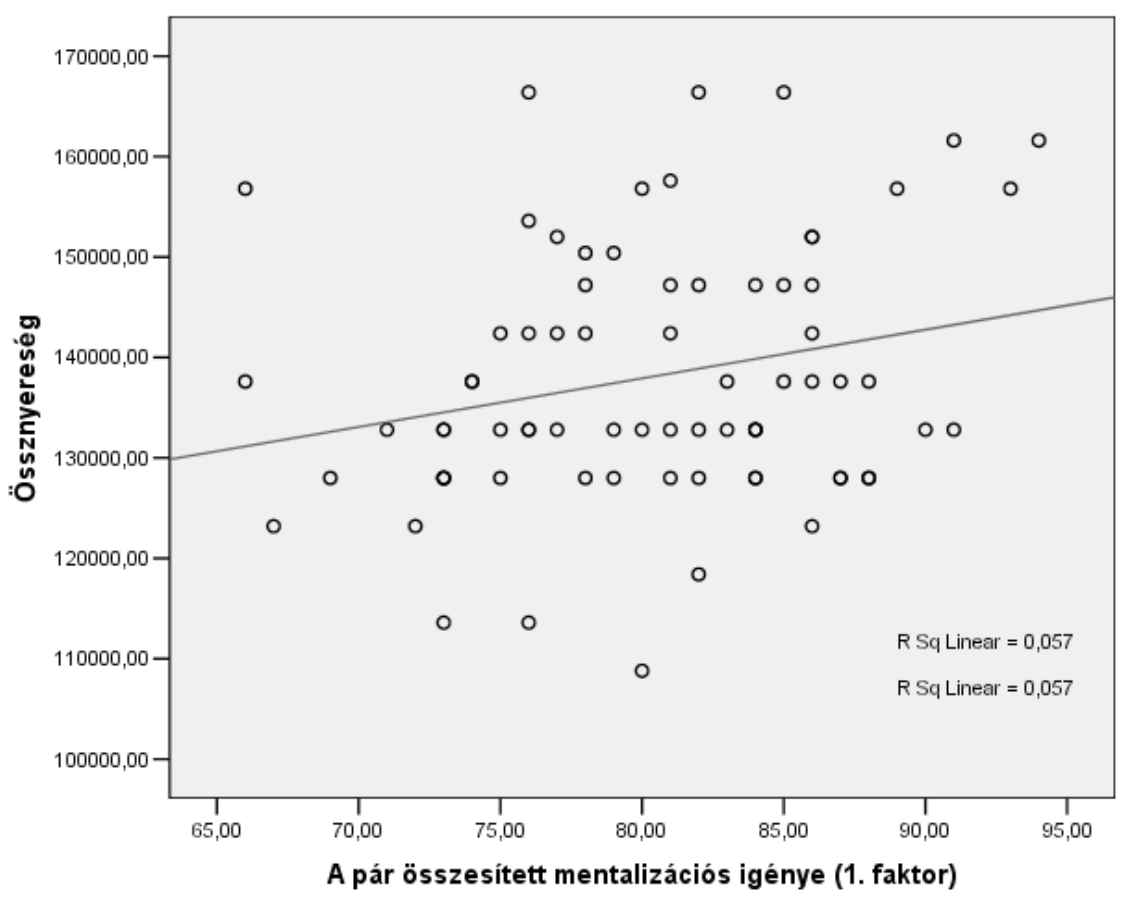

1. ábra. A pár összesített mentalizációs igényének hatása az össznyereségre

Lineáris regressziószámítással ellenőriztük, hogy a páron belül a mentalizációs igény konjunktív, diszjunktív vagy additív módon járul-e hozzá a jobb integrációs teljesítményhez, prediktorként kezelve a mentalizációs igény páron belüli összegét, minimumát és maximumát. A stepwise módszerrel meghatározott regressziós egyenlet szerint szignifikáns modellt $(d f=74 ; F=5,28 ; p<0,05)$ a maximumérték kizárólagos bennfoglalásával írhatunk le $(\beta=0,26 ; t=2,30 ; p<0,05)$. Ez azt jelenti, hogy az integrációban az a meghatározó, akinek erősebb a mentalizációs igénye, és ez a hatás a partner ilyen igényétől nem függ, vagyis a mentalizációs igénynek az integrációban diszjunktív szerepe van.

A második hipotézis teszteléséhez a tárgyalások szövegkorpuszainak elemzésére volt szükség. Az elemzési kategóriák kialakításánál nagymértékben támaszkodtunk SCHEI, Rognes és SHAPIRO (2011) munkájára. Tartalomelemzési kategóriákat alakítottunk ki, és a 75 alkutárgyalás esetében megnyilvánulásonként elemeztük a tárgyalásokat. Az elemzési kategóriákat lásd a 2. táblázatban. 
2. táblázat. Az alkutárgyalások szövegkorpuszainak elemzési szempontjai és a szempontok definíciója

\begin{tabular}{|c|c|c|}
\hline $\begin{array}{c}\text { Tartalomelemzési szem- } \\
\text { pont/kategória }\end{array}$ & Tartalomelemzési szempont definíciója & Példa \\
\hline pozitív megnyilvánulás & $\begin{array}{l}\text { pozitív, empatikus megjegyzé- } \\
\text { sek }\end{array}$ & $\begin{array}{l}\text { „Ez (amit a másik mondott) } \\
\text { meglehetősen érdekes.” }\end{array}$ \\
\hline negatív megnyilvánulás & $\begin{array}{l}\text { negatív megjegyzések, például a } \\
\text { tárgyaló a csalódását, kiábrán- } \\
\text { dultságát, nemtetszését fejezi ki } \\
\text { a másik javaslatára, vagy nega- } \\
\text { tív következményre utal: nem } \\
\text { megy bele, nem egyezik meg }\end{array}$ & „Biztos, hogy nem!” \\
\hline manipuláció & $\begin{array}{l}\text { a nyílt manipulációs befolyásolás, } \\
\text { manipulációs „technika” haszná- } \\
\text { lata } \\
\text { például viszonosság normájára } \\
\text { való hivatkozás, saját lehetősé- } \\
\text { geinek korlátosságára való hi- } \\
\text { vatkozás, zsarolás, kioktatás, } \\
\text { mellébeszélés }\end{array}$ & $\begin{array}{l}\text { „Én is engedtem, ön is } \\
\text { engedhet...” } \\
\text { „Maga mint hentes tudja } \\
\text { a legjobban...” }\end{array}$ \\
\hline $\begin{array}{l}\text { saját érdek kifejezése } \\
\text { prioritásinformációval } \\
\text { (elsődleges prioritás) }\end{array}$ & $\begin{array}{l}\text { ha a megszólalás tartalmaz in- } \\
\text { formációt arra vonatkozóan, } \\
\text { hogy mi a személy elsődleges } \\
\text { prioritása }\end{array}$ & $\begin{array}{l}\text { „Nekem jobb lenne, } \\
\text { hogyha kevesebb ter- } \\
\text { méket vennék, mint ha } \\
\text { hosszabb szállítási időt } \\
\text { hagynék.” }\end{array}$ \\
\hline $\begin{array}{l}\text { reflexió a másik prioritá- } \\
\text { saira is } \\
\text { (másodlagos prioritás) }\end{array}$ & $\begin{array}{l}\text { ha a megszólalás tartalmaz in- } \\
\text { formációt arra vonatkozóan is, } \\
\text { hogy a személy saját prioritása } \\
\text { érvényesítése mellett tekintetbe } \\
\text { veszi alkupartnerének prioritá- } \\
\text { sait is }\end{array}$ & $\begin{array}{l}\text { „Hát úgy gondoltam, } \\
\text { hogy a kiszállítási idő } \\
\text { az napi kétszer legyen, } \\
\text { a tenyésztett állatfajták, } \\
\text { amit nekem hoz az mi- } \\
\text { nimum 8-9, és fizetni, } \\
\text { pedig ahogy Ön gondol- } \\
\text { ta...” }\end{array}$ \\
\hline hazugság & $\begin{array}{l}\text { Nem tartja magát a szabályokhoz } \\
\text { a három kérdéskör/alkutéma te- } \\
\text { kintetében. (A } 3 \times 9 \text { lehetőségen } \\
\text { kívül másokat is beemel.) }\end{array}$ & $\begin{array}{l}\text { Például „3 hónapos fize- } \\
\text { tési határidő...” } \\
\text { „Csak két állatom van.” }\end{array}$ \\
\hline
\end{tabular}

Az egyéni adatokat korrelációszámítással elemezve, a másodlagos prioritással a mentalizációs igény skála összpontszáma $(r=0,13 ; p=0,1)$, illetve a mentalizációra irányuló attitűd $(r=0,13 ; p=0,09)$ mutatott tendenciaszintű, gyenge pozitív összefüggést. A mentalizációra irányuló attitűd a hazugsággal is mutat összefüggést, gyenge, de szignifikáns negatív irányút $(r=-0,18 ; p=0,03)$. A pár össze- 
sített mentalizációs igényét elemezve a mentalizációra irányuló attitűd (skála 3. faktorára adott válaszpontszámok összege a párban) a másodlagos prioritással mutat gyenge, egyenes irányú, szignifikáns összefüggést $(r=0,23 ; p=0,04)$. A pozitív, illetve negatív megnyilvánulások, valamint a manipuláció gyakorisága tekintetében nem találtunk további összefüggéseket.

A harmadik hipotézis tesztelését szerepenként végeztük el, vegyes ANOVA módszerrel, ahol a személyen belüli összetartozó adatok az egyes szempontok partner nézőpontiából ítélt fontossága voltak, a személyek közötti változó pedig a kisebb, illetve nagyobb mentalizációs igény (a mentalizációs igény skála itemeire adott átlagpontszám $M=5,74$ ( $S D=0,69)$ alattiak és fölöttiek csoportja). Emlékeztetőképp, a feladatot jól reprezentáló eladó (állatfarm-igazgató) érti, hogy a másiknak a kiszállítási idő a legfontosabb, a fizetési határidő pedig a legkevésbé fontos, s a feladatot jól értő vevő (hentesbolt-tulajdonos) érti, hogy a másiknak a fizetés a legfontosabb, a kiszállítás a legkevésbé. Eredményeink szerint mind az eladók $\left(F_{\text {Szемтопток }}(2,67)=5,54 ; p<0,01\right)$, mind a vevók $\left(F_{\text {SZемтопток }}(2,69)=\right.$ $15,01 ; p<0,01)$ rendelkeztek egyfajta helyzetnek megfeleló reprezentációval, viszont nem állíthatjuk, hogy azok a személyek, akiknek magasabb volt a mentalizációs igénye, a feladat jobb leképezésére jutottak volna, akár eladók voltak $\left(F_{\text {SZempontok } \times \text { Mentalizáció }}(2,67)=0,34 ; p=0,71\right)$, akár vevők $\left(F_{\text {SZEMPontoK } \times \text { Mentalizáció }}\right.$ $(2,69)=0,17 ; p=0,84)$. Viszont, legalábbis az eladók esetében, az erősebb mentalizációs igényủ személyek a partner összes igényét a tendenciát alig meghaladó módon átlagosan erősebbnek látták $\left(F_{\text {MENTALIZÁció }}(1,67)=2,47 ; p=0,12\right)$. (Ugyanez az érték a vásárlóknál: $\left(F_{\text {Mentalizáció }}(1,67)=0,51 ; p=0,47\right.$.

\section{MEGVITATÁS}

A tanulmány a mentalizációra irányuló igény több szempontos alkuhelyzetben betöltött szerepét mutatta be. A dolgozat beleillik abba a kutatási vonulatba, amely a mentalizációs jelenségkör szerepét az egészséges felnőtt személyek körében vizsgálja, jellemzően a proszociális társas viselkedés tekintetében. A több szempontos alkuhelyzet különösképpen azért alkalmas a mentalizációs igény hatásának a vizsgálatára, mert a mentalizációs képességgel kapcsolatban azonosított proszociális hatás az integratív alkutér kihasználásának a képében értelmezhető benne. További meghatározó jegyei, hogy teret ad a viselkedés leíró jellemzésére, amenynyiben kommunikációs stíluselemeket tesz vizsgálhatóvá, és információhiányos helyzet, ami tesztelhetővé teszi azt a kérdést, hogy a mentalizációs igény vajon a megismerésen keresztül hat-e, vagy inkább nagyon általánosan az alkalmazkodást szolgálva.

Hipotéziseinket a mentalizációs képességnek a proszociális viselkedésre való hatása alapján fogalmaztuk meg (lásd például EXLINE és mtsai, 2008; KovÁCs és mtsai, 2012; PAAL és BereczkeI, 2007; WAKABAYAShi és Katsumata, 2011). A magasabb mentalizációra irányuló igénnyel rendelkező párok, köszönhetően a pár magasabb mentalizációs igényủ tagjának, valóban jobban kihasználták az integratív alkuteret. A magasabb mentalizációs igény, összességében vagy az egyes 
faktorok szintjén, összefüggést mutatott olyan kommunikációs stílusjegyekkel, melyeket a szakirodalom az integratív tárgyalási stílus jegyeiként azonosít (Pruitt, 1981; Schei, Rognes és Shapiro, 2011; Weingart és mtsai, 2007; WEINGART és mtsai, 1990). Azt láttuk például, hogy azok a párok, akik mentalizációs tevékenységre irányuló attitűdje pozitívabb volt, több esetben tettek egymás prioritásaira vonatkozó megiegyzéseket. Vagyis többször utaltak arra, hogy a tárgyalópartnerüket hogyan érintené az ő saját prioritásaiknak az érvényesítése, tehát többször fejezték ki magukat olyan terminusokban, mely szem előtt tartja a beszélgetőpartner szempontjait is. Ez tendenciaszinten egyénileg is megmutatkozott, tehát az a személy, aki számára a mentalizáció nagyobb mértékben jelentett kedvelt tevékenységet, több esetben tett olyan megnyilvánulást, amely a társa prioritásaira is vonatkozott. Emellett minél nagyobb mértékben jelentett kedvelt tevékenységet egy egyén számára a mentalizációs tevékenység, annál kevesebb valótlan információt tartalmaztak megnyilvánulásai.

Váratlan és a mentalizációs igény hatásmechanizmusának a megismerése szempontjából fontos eredmény, hogy a nagyobb mentalizációs igény nem vezetett a probléma szerkezetének a jobb megismeréséhez. Ez arra utal, hogy az erős igény nem feltétlenül a megismerés „hideg” útjain hat, tehát nem a pontosabb problématérképen azonosított probléma tudatos megoldásának útján, hanem valószínủleg az interaktív partnernek az ő erős prioritásának mentén kezdeményezett erős törekvésére való empatikus ráhangolódáson keresztül. Ezt a feltételezett mechanizmust későbbi kutatásainkban ellenőrizni kell. Mindezek alapián azt láthatjuk, hogy a társ gondolatainak, szándékainak megismerésére irányuló magasabb igény valószínűleg indirekt módon hat, feltételezhetően a másik szempontjaira való érzékeny ráhangolódás (engedés) által, ami hatékonyabb megoldásokhoz vezet integratív helyzetben.

Vizsgálatunk korlátját jelenti, hogy a mentalizációs igény hatásának más proszociális attitűdtől, illetve a mentalizációs képességtől való elkülönítésére nem ad lehetőséget. Mindazonáltal, ha abból indulunk ki, hogy a mentalizációs igény maga is egy attitűd, amit valószínủleg erősíteni is lehet, akkor a konstruktív konfliktusmegoldási képesség fejlesztését kitűző programokban a mindenkori érintettek mentalizációs igényének az erősítése megfontolásra érdemes célkitűzés.

\title{
1. melléklet. Az alkutárgyalási feladat instrukciója
}

\author{
Instrukció - Vásárló (hentesbolt-tulajdonos)
}

Képzelje el, hogy egy hentesbolt tulajdonosa. A hentesbolt eddigi beszállítója a jövőben már nem fogja tudni ellátni az árubeszállítást, ezért felkeresett egy másik állatfarmot, hogy a gördülékeny árubeszállítás érdekében tárgyaljanak. A következő percekben lehetősége lesz találkozni az állatfarm igazgatójával, akivel megbeszélheti a részleteket.

A következő három témát érintve kellene tárgyalniuk: kiszállítási idő, áruválaszték, fizetési határidő. 
A kiszállítási idő a megrendelés kiadásától a tényleges áruátadásig eltelt időt jelenti.

Az áruválaszték a kiszállított állatfajták számát jelenti.

A fizetési határidő pedig az áruátvételtől a kifizetésig eltelt időt jelenti.

A beszélgetés időtartama alatt az említett szempontok mentén kössön üzletet az állatfarm igazgatójával, ahogyan Ön azt a legjobbnak látja.

A kiszállítási idő többek között azért fontos, hogy a húsboltban minden nap friss termék kerüljön eladásra.

Ha az árubeszállítás nem elég gyakori, akkor félő, hogy például csökkeni fog a vevőkör, a rendszertelen utánpótlás miatt.

Minél szélesebb az üzlet árukínálata annál több vevő fog betérni a boltba, mivel a szélesebb árukínálattal több vevőt tud becsalogatni.

Az ön vagyonának nagy százaléka a termékkészletben áll, ezért Önnek az az érdeke, hogy minél később fizessen, akkor, ha már a húsáruk ténylegesen eladásra kerültek.

A pontos haszon/profit kiszámítás érdekében mellékeltünk egy táblázatot, amelyből megtudhatja, hogy a kiszállítási idő, áruválaszték és fizetési határidő tekintetében milyen opciók közül választhat, és a különböző opciók mennyi hasznot jelentenek Önnek.

10 perc áll rendelkezésére felkészülni a tárgyalásra és 20 percen keresztül tárgyalhat.

Kizárólag a táblázatban leírt konkrét összegekről nem beszélhet tárgyalópartnerével, de minden másról igen.

A feladat lényege, hogy maximum 20 perc alatt megegyezzen partnerével, és az idő leteltével felírja a lapra, hogy mind a szállítási idő, mind az áruválaszték, mind pedig a fizetési határidő tekintetében melyik opcióban egyeztek meg.

A megszerzett kísérleti tallérok számát 75-tel elosztva kapja meg a forintban értendő jutalmat, ami a fix óradíjon felül értendő.

Instrukció - Eladó (állatfarm-igazgató)

Képzelje el, hogy egy állatfarm igazgatója. A farmra egy új ügyfél látogat, aki egy hentesbolt tulajdonosa, és az Önök farmjától szeretné áruját beszerezni. A következő percekben a hentesbolt tulajdonosával lesz lehetősége találkozni, akivel megbeszélheti a részleteket.

A következő három témát érintve kellene tárgyalniuk: kiszállítási idő, áruválaszték, fizetési határidő.

A kiszállítási idő a megrendelés felvételétől a tényleges áruátadásig eltelt időt jelenti.

Az áruválaszték a kiszállítandó állatfajták számát jelenti.

A fizetési határidő pedig az áruátvételtől a kifizetésig eltelt időt jelenti.

A beszélgetés időtartama alatt az említett szempontok mentén kössön üzletet a hentesbolt tulajdonosával, ahogyan Ön azt a legjobbnak látja.

A gyorsabb kiszállítási idő Önnek azért nem előnyös többek között, mert adott esetben gyakrabban kellene erre megfelelő személyzetet foglalkoztatnia, illetve a magas benzinárak csökkentik a profitot.

Önnek nem előnyös többfajta állatot tenyésztenie, mivel például gondoskodni kell külön-külön az állatok takarmányáról, szükséges gyógyszereiről, elhelyezéséről stb.

Vagyonának nagy százaléka az állatkészletben áll, ezért az az érdeke, hogy minél hamarabb fizessék ki az átvett állatot, hogy folyamatosan gondoskodni tudjon az újabb állatbeszerzésről és az állatok felneveléséről.

A pontos haszon/profit kiszámítás érdekében mellékeltünk egy táblázatot, amelyből megtudhața, hogy a kiszállítási idő áruválaszték, és fizetési határidő tekintetében milyen opciók közül választhat, és a különböző opciók mennyi hasznot jelentenek Önnek.

10 perc áll rendelkezésére felkészülni a tárgyalásra és 20 percen keresztül tárgyalhat. 
Kizárólag a táblázatban leírt konkrét összegekről nem beszélhet tárgyalópartnerével, de minden másról igen.

A feladat lényege, hogy maximum 20 perc alatt megegyezzen partnerével, és az idő leteltével felírja a lapra, hogy mind a szállítási idő, mind az áruválaszték, mind pedig a fizetési határidő tekintetében melyik opcióban egyeztek meg.

A megszerzett kísérleti tallérok számát 75-tel elosztva kapja meg a forintban értendő jutalmat, ami a fix óradíjon felül értendő.

\section{2. melléklet. Az egves megegvezési opciókhoz tartozó haszon mértéke az eladó és vásárló tekintetében}

\begin{tabular}{|c|c|c|c|c|c|c|c|c|}
\hline \multicolumn{3}{|c|}{ Kiszállítási idö } & \multicolumn{3}{|c|}{ Tenyésztett állatfajták } & \multicolumn{3}{|c|}{ Fizetési határidö } \\
\hline & 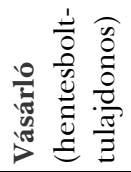 & 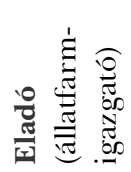 & 胥 & 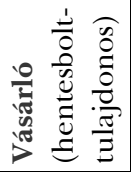 & 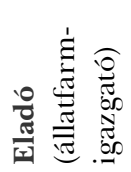 & 胥 & 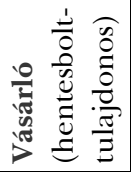 & 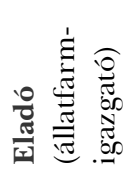 \\
\hline $\begin{array}{l}\text { naponta } \\
\text { kétszer }\end{array}$ & 64000 & 0 & 9 & 38400 & 0 & azonnal & 0 & 64000 \\
\hline $\begin{array}{l}\text { másnap } \\
\text { reggelre }\end{array}$ & 56000 & 3200 & 8 & 33600 & 4800 & $\begin{array}{l}1 \text { nap } \\
\text { múlva }\end{array}$ & 3200 & 56000 \\
\hline $\begin{array}{l}\text { másnap } \\
\text { délutánra }\end{array}$ & 48000 & 6400 & 7 & 28800 & 9600 & $\begin{array}{l}\text { 2-3 nap } \\
\text { múlva }\end{array}$ & 6400 & 48000 \\
\hline 2 napra & 40000 & 9600 & 6 & 24000 & 14400 & $\begin{array}{l}\text { 4-5 nap } \\
\text { múlva }\end{array}$ & 9600 & 40000 \\
\hline 2,5 napra & 32000 & 12800 & 5 & 19200 & 19200 & $\begin{array}{l}1 \text { hét } \\
\text { múlva }\end{array}$ & 12800 & 32000 \\
\hline 3 napra & 24000 & 16000 & 4 & 14400 & 24000 & $\begin{array}{l}10 \text { nap } \\
\text { múlva }\end{array}$ & 16000 & 24000 \\
\hline 3,5 napra & 16000 & 19200 & 3 & 9600 & 28800 & $\begin{array}{l}2 \text { hét } \\
\text { múlva }\end{array}$ & 19200 & 16000 \\
\hline 4 napra & 8000 & 22400 & 2 & 4800 & 33600 & $\begin{array}{l}3 \text { hét } \\
\text { múlva }\end{array}$ & 22400 & 8000 \\
\hline 4,5 napra & 0 & 25600 & 1 & 0 & 38400 & $\begin{array}{l}1 \text { hónap } \\
\text { múlva }\end{array}$ & 25600 & 0 \\
\hline
\end{tabular}

\section{IRODALOM}

Ali, F., \& Chamorro-Premuzic, T. (2010). Investigating Theory of Mind deficit in non clinical psychopathy and Machiavellianism. Personality and Individual Differences, 49, $169-174$.

Bazerman, M. H., Curhan, J. R., Moore, D. A., \& Valley, K. L. (2000). Negotiation. Annual Review of Psychology, 51, 279-314.

BERNÁTH Á. (2014). Az elmeolvasás és az elmeolvasásra irányuló igény szerepe egészséges felnött személyek társas viselkedésében. Doktori (Ph.D.) értekezés, Debrecen. 
BERNÁTH Á. és KovÁCS J. (2013). A mentalizációs igény és a machiavelliánus nézetekkel való egyetértés. Magyar Pszichológiai Szemle, 68(4), 671-685.

BERNÁTH Á. és KovÁCS J. (2014). A mentalizációra irányuló igény társas viselkedésben betöltött szerepe. In MünNICH Á. (Szerk.), Pszichológiai Kutatások. Debreceni Egyetem Pszichológiai Doktori Program (pp. 85-98). Debrecen: Debreceni Egyetemi Kiadó.

De Dreu, C. K. W., Beersma, B., Steinel, W., \& Van Kleef, G. A. (2007). The psychology of negotiation. Principles and basic processes. In A. W. KruglansKi, \& T. E. HigGins (Eds.), Social Psychology: Handbook of Basic Principles (2nd ed.) (608-629). New York, NY: Guilford Press.

De Dreu, C. K. W., Beersma, B., Stroebe, K., \& Euwema, M. C. (2006). Motivated information processing, strategic choice, and the quality of negotiated agreement. Journal of Personality and Social Psychology, 90, 927-943.

De Dreu, C. K. W., Weingart, L. R., \& KWON, S. (2000). Influence of social motives on integrative negotiation: A meta-analytic review and test of two theories. Journal of Personality and Social Psychology, 78, 889-905.

Deutsch, M., \& Krauss, R. M. (1981). A fenyegetés hatása az interperszonális alkura. In CSEPELI Gy. (szerk.), A kísérleti társadalomlélektan fö́rama (393-414). Budapest: Gondolat.

ESPERGER Zs., \& BERECZKEI T. (2011). Törekvés mások belső világának feltérképezésére: spontán mentalizáció és machiavellizmus, Magyar Pszichológiai Szemle, 66(3), 487-506.

Exline, J. J., Baumeister, R. F., Zell, A. L., Kraft, A. I., \& Witwliet, C. V. O. (2008). Not so innocent: Does seeing one's own capability for wrongdoing predict forgiveness? Journal of Personality and Social Psychology, 94, 495-515.

Ferguson, F., \& Austin, E. J. (2010). Associations of trait and ability emotional intelligence with performance on Theory of Mind tasks in an adult sample. Personality and Individual Differences, 49, 414-418.

Kinderman, P., Dunbar, R., \& Bentall, R. P. (1998). Theory of mind deficits and causal attributions. British Journal of Psychology, 89, 191-204.

Kovács J., PÁntya .J., Bernáth Á., Máth .J. és Hidegkuti I. (2012). „Elég-e már a rosszból?” - Az eszkalálódó konfliktusból való kilépés kísérletes vizsgálata a viszonzatlan békülési gesztus és a mentalizációs képesség függvényében. Magyar Pszichológiai Szemle, 67(4), 653-671.

Lyons, M., Caldwell, T., \& Shultz, S. (2010). Mind-reading and manipulation- is machiavellianism related to theory of mind? Journal of Evolutionary Psychology, 8, 261-274.

MAIO, G. R., \& Esses, V. M. (2001). The need for affect: Individual differences in the motivation to approach or avoid emotions. Journal of Personality, 69, 583-614.

McCullough, M. E., Worthington, E. L., \& RaChal, K. C. (1997). Interpersonal forgiving in close relationships. Journal of Personality and Social Psychology, 73, 321-336.

PaAl, T., \& BereczkeI, T. (2007). Adult theory of mind, cooperation, Machiavellianism: The effect of mindreading on social relations. Personality and Individual Differences, 43, $541-551$.

PAPP G., BERNÁTH Á. és TóTH E. (2014). A mentalizációra irányuló igény és a jóvátétel hatása a megbocsátásra közeli és távoli kapcsolatban. In MÜNNICH Á. (szerk.), Pszichológiai Kutatások. Debreceni Egyetem Pszichológiai Doktori Program (99-110). Debrecen: Debreceni Egyetemi Kiadó.

PruitT, D. G. (1981). Negotiation Behavior. New York, NY: Academic Press. 
PruitT, D. G. (2012). A history of social conflict and negotiation research. In A. W. Kruglanski, \& W. STroebe (Eds.), Handbook of the History of Social Psychology (431-452). New York: Psychology Press.

PruitT, D. G., \& LEWIS, S. A. (1975). Development of integrative solutions in bilateral negotiation. Journal of Personality and Social Psychology, 31, 621-633.

Pruitt, D. G., \& Rubin, J. Z. (1986). Social Conflict: Escalation, Stalemate, and Settlement. New York: Random House.

SCHEI, V., Rognes, I. K., \& SHAPIRO, D. L. (2011). Can individualists and cooperators play together? The effect of mixed social motives in negotiations. Journal of Experimental Social Psychology, 47, 371-377.

Slaughter, V., \& Repacholi, B. (2003). Introduction. Individual differences in Theory of Mind. What are we investigating? In B. RePaCholi, \& V. SLAUGHTER (Eds.), Individual Differences in Theory of Mind (1-12). New York, NY: Psychology Press.

Tomasello, M. (2002). Gondolkodás és kultúra. Budapest: Osiris.

Van Lange, P. A. M., \& De Dreu, C. K. W. (2007). Társas interakció: együttműködés és versengés. In M. Hewstone és W. STroebe (szerk.), Szociálpszichológia (305-330). Budapest: Akadémiai Kiadó.

WAKABAYASHI, A., \& KATSUMATA, A. (2011). The motion picture mind reading test: measuring individual differences of social cognitive ability in a young adult population in Japan, Journal of Individual Differences, 32, 55-64.

Weingart, L. R., Brett, I. M., Olekalns, M., \& Smith, P. L. (2007). Conflicting social motives in negotiating groups. Journal of Personality and Social Psychology, 93, 994-1010.

Weingart, L. R., Thompson, L. L., Bazerman, M. H., \& Carroll, I. S. (1990). Tactical behavior and negotiation outcomes. International Journal of Conflict Management, 1, 7-31.

\title{
THE NEED FOR MENTALIZING AND COOPERATION IN INTEGRATIVE NEGOTIATION
}

\author{
BERNÁTH, ÁGNES - KOVÁCS, JUDIT
}

The need for mentalizing is a special motivation for mapping other's mental states (such as beliefs, emotions, and motives). The studies in the field of mentalization referred so far to the role of mentalizing achievement (or ability) in social behavior, specifically, in prosocial behavior.

The present study examines the role of need for mentalizing in multi-issues negotiation. In our expectations the higher need for mentalizing helps people in concluding about negotiation-partners' priorities (by mapping their partners' mental states), thus in achieving mutually beneficial agreements.

According to the results from 75 negotiations the strong need for mentalizing contributes to integrative outcomes, however not by the accurate representation of the structure of the negotiation task, but by stronger adjustment to the partner's needs. Furthermore, the strong need for mentalizing correlated with the integrative behavior style.

Key words: mentalizing ability, need for mentalizing, multi-issues negotiation 